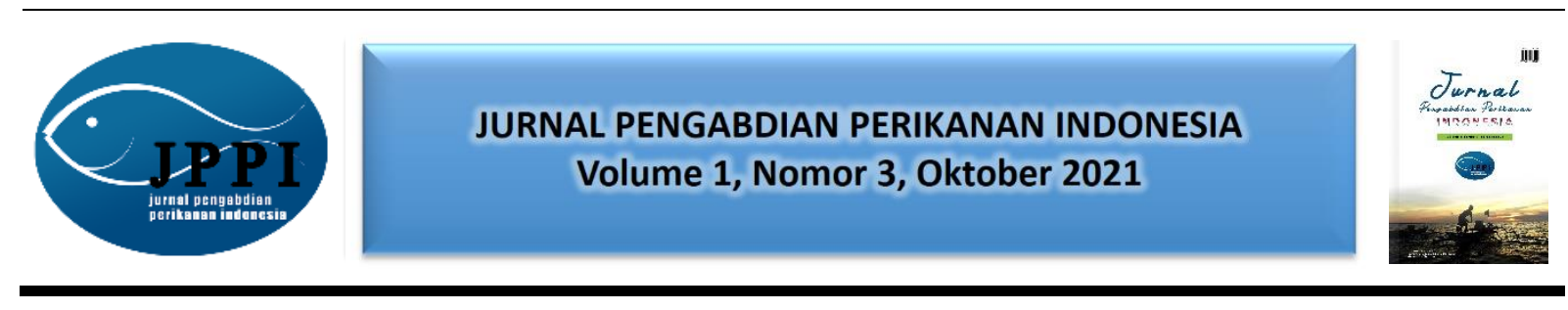

\title{
PENAMBAHAN KONSORSIUM BAKTERI DAN AERASI PADA UPAYA PENURUNAN BAHAN ORGANIK AIR SISA BUDIDAYA UDANG VANAME (Litopenaeus vannamei)
}

\author{
Dini Alvateha*, Diana Arfiati, Shofiatul Lailiyah \\ Program Studi Manajemen Sumberdaya Perairan, Universitas Brawijaya \\ * Jalan Veteran, Kota Malang, Provinsi Jawa Timur \\ *Alamat korespondensi : dinialvateha@student.ub.ac.id
}

(Tanggal Submission: : 9 September 2021, Tanggal Accepted : 31 Oktober 2021)

\begin{abstract}
Keyword: Abstrak :
Air limbah, Air limbah tambak udang yang akan dibuang ke perairan umum harus memenuhi Bahan baku mutu yang berlaku agar tidak mencemari perairan setempat. Manajemen organik, limbah budidaya yang baik merupakan salah satu cara yang dapat dilakukan. Konsorsium Penambahan konsorsium bakteri dan aerasi diduga mampu mempercepat bakteri, penurunan bahan organik pada air limbah. Tujuan dari kegiatan ini adalah untuk Aerasi, mendapatkan penurunan kadar bahan organik dan kadar karbondioksida terbanyak Tutupan dengan waktu tersingkat pada air sisa budidaya udang vaname (Litopenaeus vannamei) dengan penambahan konsorsium bakteri dan aerasi. Metode yang digunakan dalam penelitian ini yaitu metode eksperimen. Rancangan penelitian disusun dalam rancangan acak lengkap menggunakan 6 perlakuan yakni perlakuan aerasi, tanpa aerasi, tutupan, kontrol aerasi, kontrol tanpa aerasi, dan kontrol tutupan dengan 4 kali ulangan. Berdasarkan uji Tukey hasil terbaik dalam penurunan bahan organik didapatkan pada perlakuan tutupan dengan penambahan konsorsium bakteri pada jam ke-30 yang mengalami penurunan $99,34 \%$, kadar bahan organik awal $61 \mathrm{mg} / \mathrm{L}$ menjadi 0,4 mg/L. Penurunan kadar karbondioksida tercepat yakni pada perlakuan penambahan aerasi dan konsorsium bakteri pada jam ke-186 dapat menurunkan kadar karbondioksida (dari kadar awal 29,6 mg/L menjadi $0 \mathrm{mg} / \mathrm{L}$ ). Kualitas air dapat mempengaruhi kerja dari bakteri yang menguraikan bahan organik dan menghasilkan karbondioksida. Penurunan kadar bahan organik terbanyak dengan waktu tersingkat yakni dengan perlakuan tutupan pada jam ke-30, dan penurunan karbondioksida terbanyak dengan waktu tersingkat dengan perlakuan aerasi pada jam ke-186.
\end{abstract}

Panduan Sitasi (APPA $7^{\text {th }}$ edition):

Alvateha, D., Arfiati, D., \& Lailiyah, S. (2021). Penambahan Konsorsium Bakteri dan Aerasi Pada Upaya Penurunan Bahan Organik Air Sisa Budidaya Udang Vaname (litopenaeus vannamei). Jurnal Pengabdian Perikanan Indonesia, 1 (3), 225-230. http://doi.org/ 10.29303/jppi.v1i3.343 


\section{PENDAHULUAN}

Udang vaname (Litopenaeus vannamei) termasuk komoditas sektor perikanan yang memiliki permintaan tinggi. Upaya untuk mengembangkan perikanan budidaya sampai saat ini terus dilakukan terutama pada sistem budidaya intensif, berbagai kendala dihadapi seperti buangan limbah akuakultur (Adipu, 2019). Dampak dari limbah buangan tambak jika terus menerus dikeluarkan tanpa didahului dengan perlakuan penurunan bahan organik dapat menurunkan kualitas perairan umum penerima limbah tersebut (Romadhona et al., 2016).

Upaya pengelolaan yang dapat dilakukan untuk menurunkan kadar bahan organik salah satunya dengan metode bioremediasi menggunakan bakteri (Arfiati et al., 2020). Enzim-enzim yang diproduksi oleh mikroorganisme tersebut memodifikasi struktur polutan beracun menjadi tidak kompleks sehingga menjadi metabolit yang tidak beracun dan berbahaya (Priadie, 2012). Mikroorganisme menggunakan bahan organik sebagai sumber makanannya dan kemudian akan mengubahnya menjadi biomassa dan karbondioksida.

Penambahan aerasi diduga mampu mempercepat penurunan bahan organik dan karbondioksida di perairan. Pengaruh aerasi dalam penurunan bahan organik disebabkan oleh adanya injeksi udara dari aerator yang meningkatkan kandungan oksigen terlarut pada air limbah. Nilai oksigen terlarut yang semakin tinggi pada air limbah akan meningkatkan aktivitas mikroorganisme di dalamnya untuk mendekomposisi bahan organik. Karbondioksida di perairan diduga dapat mengalami penurunan dengan adanya bantuan aerasi yang menyebabkan terjadinya pengadukan sehingga mempercepat penurunan karbondioksida. Tujuan dari kegiatan ini yaitu untuk mengetahui penurunan kadar bahan organik dan kadar karbondioksida terbanyak dengan waktu tersingkat pada air sisa budidaya udang vaname dengan penambahan konsorsium bakteri dan aerasi.

\section{METODE KEGIATAN}

Penelitian dilaksanakan pada bulan Januari hingga Februari 2021. Sampel air diambil dari PT. Anugerah Tanjung Gumukmas Kabupaten Jember. Pengukuran kualitas air dilakukan di laboratorium UPT Perikanan Air Tawar Fakultas Perikanan dan Ilmu Kelautan Universitas Brawijaya di Sumber Pasir, Pakis, Malang, Jawa Timur.

Penelitian yang dilakukan menggunakan 6 perlakuan yakni perlakuan aerasi, tanpa aerasi, tutupan, kontrol aerasi, kontrol tanpa aerasi, dan kontrol tutupan dengan 4 kali ulangan. Pengkuran kadar bahan organik dan karbondioksida serta parameter kualitas air lainnya (suhu, pH, oksigen terlarut, dan salinitas) dilakukan setiap 6 jam sekali.

Metode yang digunakan dalam kegiatan ialah metode eksperimen dengan rancangan acak lengkap (RAL) dan analisa data dengan uji ANOVA yang dilanjutkan dengan Uji Tukey menggunakan software SPSS (Statistical Package for Sosial Science) Statistic 16.

\section{HASIL DAN PEMBAHASAN}

\section{Analisa Bahan Organik}

Pemberian perlakuan berupa penambahan konsorsium bakteri dan aerasi, tanpa aerasi, serta tutupan diduga mempercepat penurunan bahan organik pada air sisa budidaya udang vaname (Litopenaeus vannamei) karena ketersediaan oksigen yang cukup dalam penurunan bahan organik secara aerob akan mempercepat proses penguraian bahan organik sehingga membentuk karbondioksida, dan pada perlakuan tutupan bakteri yang bersifat anaerob dapat bekerja lebih baik dalam menguraikan bahan organik. 
Nilai bahan organik air sampel pada awal penelitian yakni senilai $61 \mathrm{mg} / \mathrm{L}$, kemudian setelah diberi perlakuan menurun menjadi $0,4 \mathrm{mg} / \mathrm{L}$. Berdasarkan hasil penelitian dapat diketahui bahwa penurunan kadar bahan organik paling optimal terjadi pada jam ke-66, yang dimana pada jam tersebut semua perlakuan mencapai nilai terendah bahan organik, sedangkan untuk waktu tercepat berdasarkan uji Tukey didapatkan hasil terbaik pada penelitian yaitu perlakuan tutupan dengan penambahan konsorsium bakteri pada jam ke-30 dengan kadar bahan organik awal $61 \mathrm{mg} / \mathrm{L}$ menjadi $0,4 \mathrm{mg} / \mathrm{L}$ (penurunan sebesar 99,34\%), sedangkan efisiensi penurunan kadar bahan organik terendah yaitu pada perlakuan penambahan konsorsium bakteri dan aerasi dengan kadar bahan organik awal sebesar $61 \mathrm{mg} / \mathrm{L}$ menjadi 7,6 mg/L (penurunan sebesar 87,55\%). Perlakuan penambahan konsorsium bakteri tanpa aerasi mampu menurunkan kadar bahan organik sebesar $94,59 \%$ dengan kadar bahan organik awal sebesar $61 \mathrm{mg} / \mathrm{L}$ menjadi $3,3 \mathrm{mg} / \mathrm{L}$, yang artinya perlakuan ini lebih efektif dalam menurunkan kadar bahan organik dibandingkan dengan perlakuan aerasi.

Mikroorganisme dapat mengonsumsi polutan organik dan mengubah polutan organik tersebut menjadi karbondioksida, air, dan energi untuk pertumbuhan dan reproduksinya. Perlakuan dengan tutupan berdasarkan hasil pengamatan mampu menurunkan bahan organik lebih cepat dikarenakan konsorsium bakteri yang digunakan mengandung bifido bacteria yang dapat bekerja secara baik dalam keadaan anaerob fakultatif, yakni dapat hidup dengan keberadaan oksigen dan akan lebih baik jika tidak terdapat oksigen. Penguraian bahan organik dengan perlakuan tutupan atau secara anaerob lebih baik daripada dengan penambahan aerasi, hal ini dikarenakan proses dekomposisi secara aerobik terus berlangsung sepanjang kandungan oksigen terlarut masih ada dalam air limbah hingga mencapai minimum yang mengakibatkan mikroorganisme aerobik mati, selanjutnya proses dekomposisi diambil alih tugasnya dengan proses anaerobik. Proses dekomposisi anaerobik berlangsung sebagai kelanjutan proses aerobik untuk mendekompoisisikan bahan organik yang masih ada dalam air limbah dengan bantuan mikroorganisme anaerobik.

\section{Analisa Karbondioksida}

Karbondioksida yang terkandung pada air sampel berasal dari hasil respirasi bakteri dalam menguraikan bahan organik. Pemberian perlakuan mampu mempercepat penurunan kadar karbondioksida. Nilai karbondioksida air sampel pada awal penelitian yakni senilai $29,6 \mathrm{mg} / \mathrm{L}$. Berdasarkan hasil penelitian menunjukkan bahwa pemberian perlakuan mampu mempercepat penurunan kadar karbondioksida dengan penurunan paling optimal terjadi pada jam ke-186. Berdasarkan uji Tukey didapatkan hasil terbaik pada penelitian yaitu penambahan aerasi dan konsorsium bakteri pada jam ke-186 dengan kadar karbondioksida awal 29,6 mg/L menjadi $0 \mathrm{mg} / \mathrm{L}$ (penurunan sebesar 100\%), sedangkan efisiensi penurunan kadar karbondioksida terendah yaitu pada perlakuan kontrol tutupan dengan kadar karbondioksida awal sebesar 29,6 mg/L menjadi 3,5 mg/L (penurunan sebesar $88,18 \%$ ). Perlakuan penambahan konsorsium bakteri tanpa aerasi mampu menurunkan kadar karbondioksida sebesar 89,86\% pada jam ke-186 dengan kadar awal karbondioksida 29,6 mg/L menjadi $3 \mathrm{mg} / \mathrm{L}$.

Karbondioksida timbul karena adanya proses penguraian serta pembusukan bahan organik dan proses respirasi organisme, semakin tinggi penguraian dan pelapukan bahan organik diikuti dengan semakin tingginya kadar karbondioksida dalam air. Penambahan aerasi menyebabkan terjadinya proses aerobik dengan penyisihan bahan organik yang utama berasal dari aktivitas respirasi. Reaksi aerob menunjukkan peranan oksigen dalam memecah rantai organik menjadi bentuk lain yakni $\mathrm{CO}_{2}$ dan $\mathrm{H}_{2} \mathrm{O}$ (Shelef et al., 2013). Karbondioksida tersebut nantinya yang akan 
dimanfaatkan oleh konsorsium bakteri yang bersifat anaerob sehingga mampu menurunkan kadar karbondioksida.

Penurunan kadar karbondioksida pada perlakuan aerasi dikarenakan adanya aerasi yang dapat membantu menguraikan karbondioksida serta pemanfaatan karbondioksida oleh konsorsium bakteri yang bersifat anaerob. Bakteri anaerob tersebut memperoleh energinya dari oksidasi bahan organik kompleks tanpa menggunakan oksigen terlarut tetapi menggunakan senyawa-senyawa lain sebagai pengoksidasi. Senyawa pengoksidasi selain oksigen yang dapat digunakan contohnya karbondioksida, sulfat dan nitrat. Kebutuhan karbondioksida tersebut diperoleh dari substrat atau hasil produksi dari proses oksidasi bahan organik.

\section{Parameter Kualitas Air}

Hasil pengukuran suhu pada penelitian yakni berkisar $23-26,1{ }^{\circ} \mathrm{C}$. Nilai tersebut tergolong baik untuk menunjang pertumbuhan bakteri dan sesuai dengan baku mutu limbah cair. Pertumbuhan bakteri sebagian besar mencapai optimal pada suhu berkisar $20-45^{\circ} \mathrm{C}$ yang disebut mesofilik (Riski, 2016). Suhu berpengaruh terhadap kerja enzim pada bakteri dimana semakin tinggi suhu maka proses enzimatis atau metabolisme bakteri akan semakin meningkat sehingga aktivitas penguraian bahan organik akan semakin cepat, apabila suhu di bawah suhu optimum maka aktivitas enzim akan rendah, hal ini terjadi karena struktur tiga dimensi enzim mulai berubah sehingga substrat tidak dapat berikatan dengan sisi aktif enzim akibatnya proses katalis tidak dapat berlangsung secara sempurna (Nurkhotimah et al., 2017).

Hasil pengukuran $\mathrm{pH}$ pada penelitian yakni berkisar antara 8-9. Nilai $\mathrm{pH}$ tersebut baik untuk menunjang kehidupan bakteri. Nilai derajat keasaman untuk kehidupan mikroba yaitu antara pH 5-9 (Sari et al., 2013). Berdasarkan hasil penelitian nilai pH memiliki hubungan dengan nilai bahan organik dan kadar karbondioksida. Perlakuan aerasi memiliki nilai pH lebih tinggi dibandingkan dengan perlakuan tanpa aerasi dan tutupan karena keberadaan aerasi mampu mengurangi kadar karbondioksida yang bersifat asam sehingga nilai $\mathrm{pH}$ menjadi lebih tinggi. Konsentrasi $\mathrm{CO}_{2}$ yang semakin tinggi maka nilai pH akan semakin rendah (lebih asam) begitu pula sebaliknya (Suoth \& Nazir, 2016). Bahan organik yang diuraikan oleh mikroorganisme semakin banyak maka nilai pH semakin asam dan jika semakin sedikit bahan organik yang diuraikan maka semakin basa nilai pH, oleh karena itu perlakuan aerasi yang memiliki nilai $\mathrm{pH}$ lebih tinggi maka penguraian bahan organiknya berlangsung lebih lama dan pada perlakuan tutupan yang memiliki nilai $\mathrm{pH}$ lebih rendah maka penguraian bahan organiknya lebih cepat. Nilai pH yang semakin menurun disebabkan semakin meningkatnya buangan metabolisme kemudian terjadi proses dekomposisi sehingga menyebabkan perairan menjadi asam, selain itu penurunan $\mathrm{pH}$ disebabkan peningkatan karbondioksida akibat respirasi (Jumaidi et al., 2016).

Hasil pengukuran oksigen terlarut pada penelitian yakni berkisar 3-8,6 mg/L. Fungsi aerasi dalam pengolahan air limbah adalah meningkatkan kadar oksigen terlarut dalam air serta melepaskan kandungan gas-gas yang terlarut dalam air, sehingga pada perlakuan tanpa pemberian aerasi dan perlakuan anaerob atau dengan tutupan menunjukkan nilai oksigen terlarut yang lebih rendah. Berdasarkan hasil penelitian nilai oksigen terlarut memiliki hubungan dengan kadar bahan organik dan karbondioksida. Nilai oksigen terlarut berbanding terbalik dengan penurunan kadar bahan organik yakni semakin tinggi oksigen telarut maka penguraian bahan organik semakin lambat begitupun sebaliknya, hal ini dikarenakan konsorsium bakteri yang digunakan bersifat anaerob fakultatif sehingga bekerja lebih optimum pada kondisi oksigen yang rendah. Nilai oksigen terlarut berbanding lurus dengan penurunan karbondioksida yakni semakin tinggi oksigen terlarut maka 
semakin cepat penurunan kadar karbondioksida begitupun sebaliknya, hal ini dikarenakan keberadaan oksigen terlarut dari aerasi mampu mempercepat penguapan karbondioksida ke atmosfer, sementara pada perlakuan tutupan penurunan karbondioksida berlangsung lebih lama. Pernyataan ini sesuai dengan penelitian terdahulu bahwa pemberian aerasi pada lokasi penelitian selama dua minggu akan menurunkan kadar karbondioksida, sementara untuk lokasi tanpa aerasi konsentrasi karbondioksida meningkat.

Hasil pengukuran salinitas pada penelitian yakni berkisar 33,8-40 ppt. Konsorsium bakteri yang digunakan dalam penelitian ini mampu bertahan pada salinitas 33 hingga 40 ppt, hal ini ditandai dengan semakin berkurangnya bahan organik pada air limbah yang menandakan bakteri dapat bekerja dengan baik dalam menguraikan bahan organik tersebut. Berdasarkan hasil penelitian menunjukkan pada nilai salinitas yang lebih rendah maka penguraian bahan organik berlangsung lebih cepat begitupun sebaliknya. Nilai salinitas yang tinggi maka penguraian bahan organik oleh bakteri berlangsung lebih lama dikarenakan semakin tinggi kadar salinitas maka kelimpahan bakteri akan semakin berkurang sehingga proses penguraian bahan organik berlangsung lebih lama. Nilai salinitas yang semakin tinggi maka kelimpahan bakteri semakin berkurang karena mampu menghambat pertumbuhan koloni bakteri sehingga menyebabkan tingkat aktivitas bakteri sangat rendah akibatnya terjadinya shock osmotic atau toksik (Yulma et al., 2017). Perlakuan aerasi diduga memiliki nilai kelimpahan bakteri yang semakin berkurang karena tingginya nilai salinitas. Perlakuan tutupan memiliki kadar salinitas yang lebih rendah dan kadar karbondioksida yang lebih tinggi, hal ini diduga semakin tingginya total bakteri yang menguraikan bahan organik karena bakteri yang digunakan ialah bersifat anaerob fakultatif sehingga dapat bekerja lebih baik pada kondisi tidak ada oksigen atau pada kadar oksigen yang rendah.

\section{KESIMPULAN DAN SARAN}

Penurunan bahan organik dengan perlakuan penambahan konsorsium bakteri tanpa aerasi sebesar 94,59\%, dengan menggunakan aerasi sebesar 87,55\%, dan tutupan sebesar 99,34\%. Penurunan kadar karbondioksida dengan perlakuan penambahan konsorsium bakteri tanpa aerasi sebesar $89,86 \%$, dengan menggunakan aerasi sebesar $100 \%$, dan tutupan sebesar $88,18 \%$. Penurunan kadar bahan organik terbanyak dengan waktu tersingkat yakni dengan perlakuan tutupan pada jam ke-30, dan penurunan karbondioksida terbanyak dengan waktu tersingkat dengan perlakuan aerasi pada jam ke-186.

Perlakuan terbaik dalam penurunan bahan organik ialah penambahan konsorsium bakteri dan tutupan. Perlakuan terbaik dalam penurunan kadar karbondioksida ialah penambahan konsorsium bakteri dan aerasi. Perlakuan terbaik dalam menurunkan bahan organik dan karbondioksida secara bersamaan ialah dengan penambahan konsorsium bakteri dengan aerasi.

\section{DAFTAR PUSTAKA}

Adipu, Y. (2019). Profil Kualitas Air pada Budidaya Udang Vaname (Litopenaeus Vannamei) Sistem Bioflok dengan Sumber Karbohidrat Gula Aren. JURNAL MIPA, 8(3), 122-125. https://doi.org/10.35799/jmuo.8.3.2019.25967

Arfiati, D., Lailiyah, S., Dina, K. F., \& Cokrowati, N. (2020). Dinamika Jumlah Bakteri Bacillus subtilis dalam Penurunan Kadar Bahan Organik TOM Limbah Budidaya Ikan Lele Sangkuriang (Clarias gariepinus). Journal of Fisheries and Marine Research, 4(2), 222-226. http://dx.doi.org/10.21776/ub.jfmr.2020.004.02.6

Jumaidi, A., Yulianto, H., \& Efendi, E. (2016). Pengaruh Debit Air terhadap Perbaikan Kualitas Air pada Sistem Resirkulasi dan Hubungannya dengan Sintasan dan Pertumbuhan Benih Ikan 
Gurame (Oshpronemus gouramy). e-Jurnal Rekayasa dan Teknologi Budidaya Perairan, 5(2), 587-596. http://jurnal.fp.unila.ac.id/index.php/bdpi/article/view/1489

Nurkhotimah, B., Yulianti, E., \& Rakhmawati, A. (2017). Pengaruh Suhu dan pH terhadap Aktivitas Enzim Fosfatase Bakteri Termofilik Sungai Gendol Pasca Erupsi Merapi. Jurnal Prodi Biologi, 6(8), 465-471.

Riski, B. (2016). Pengaruh pH dan suhu terhadap produksi antibiotika dari isolat bakteri endofitik pada tumbuhan andalas (Morus macroura Miq.) (Doctoral dissertation). Universitas Andalas). Padang (ID): Universitas Andalas. http://scholar.unand.ac.id/id/eprint/20030

Romadhona, B., Yulianto, B., \& Sudarno. (2016). Fluktuasi Kandungan Amonia dan Beban Cemaran Lingkungan Tambak Udang Vaname Intensif dengan Teknik Panen Parsial dan Panen Total. Jurnal Saintek Perikanan, 11(2), 84-93. https://doi.org/10.14710/ijfst.11.2.84-93

Sari, F. R., Annissa, R., \& Tuhuloula, A. (2013). Perbandingan Limbah dan Lumpur Aktif terhadap Pengaruh Sistem Aerasi pada Pengolahan Limbah CPO. Konversi, 2(1), 39-44. http://konversi.ulm.ac.id/index.php/konversi/article/view/20

Shelef, O., Gross, A., \& Rachmilevitch, S. (2013). Role of Plants in a Constructed Wetland: Current and New Perspectives. Water, 5(2), 405-419. https://doi.org/10.3390/w5020405

Suoth, A. E., \& Nazir, E. (2016). Karakteristik Air Limbah Rumah Tangga (Grey Water) pada Salah Satu Perumahan Menengah ke Atas yang Berada di Tangerang Selatan. Ecolab, 10(2), 8088. https://doi.org/10.20886/jklh.2016.10.2.80-88

Yulma, Y., Ihsan, B., Sunarti, S., Malasari, E., Wahyuni, N., \& Mursyban, M. (2017). Identifikasi Bakteri pada Serasah Daun Mangrove yang Terdekomposisi di Kawasan Konservasi Mangrove dan Bekantan (KKMB) Kota Tarakan. Journal of Tropical Biodiversity and Biotechnology, 2(1), 28-33. https://doi.org/10.22146/jtbb.27173 